\title{
DOI https://doi.org/ 10.29303/baktinusa.v2i1.37. CAPTA (CUPCAKETAUGE) SEBAGAI INOVASI PENGEMBANGAN USAHA DI LINGKUNGAN PUNIA KECAMATAN MATARAM
}

\author{
Sultan ${ }^{1}$, Salsa Bani Indah Putri², Ayu Futriyani Jannah ${ }^{3}$, Nitania Surgawa ${ }^{4}$, Nita \\ Jayanti ${ }^{5}$, Uswatun Hasanah Yarfaryh ${ }^{6}$ \\ Email:sultandarma@yahoo.ac.id, Salsabani20@gmail.com, ayuputriani644@gmail.com, \\ nitaniasurgawa@gmail.com, Jayantinita33@gmail.com, Uswatunyarfaryh260@gmail.com \\ ${ }^{1}$ Program Teknik Elektro Fakultas Teknik Universitas Mataram \\ 2Program Studi IImu Hukum Fakultas Hukum Universitas Mataram \\ ${ }^{3}$ Program Studi IImu Sosial dan Politik Universitas Mataram \\ ${ }^{4}$ Progam Studi IImu dan Teknologi Pangan Fakultas Teknologi Pangan dan Agroindustri Universitas \\ Mataram
}

Article history: Received: 28Februari $2021 \quad$ Revised: 07Maret $2021 \quad$ Accepted: 09Maret 2021

Corresponding author: Salsa Bani Indah Putri, Jurusan IImu Hukum, Universitas Mataram, Email: Salsabani20@gmail.com

\begin{abstract}
ABSTRAK
Kelurahan Punia didominasi oleh $36 \%$ masyarakat belum bekerja dan sisanya sebagai produsen BUSLON (bus-busan dan lontong) atau disebut sebagai tauge dan lontong. Namun, usaha ini tidak mengalami pengembangan dan hanya dijual secara mentah di pasar atau sebagai olahan pendamping makanan. Sehingga diperlukan inovasi produk dengan memanfaatkan potensi wilayah tersebut yaitu tauge. Metode pelaksanaan dari Kegiatan KKN (Kuliah Kerja Nyata) P1000WB yaitu observasi lapangan, untuk memahami potensi dan mencari mitra produsen tauge, sosialisasi inovasi produk, pelaksanaan program (produksi dan pemasaran). Program kegiatan pengabdian ini terdiri dari tiga program utama. Kegiatan pertama yaitu sosialisasi inovasi produk, yang diikuti oleh 20 perwakilan masyarakat wilayah Punia menggunakan sistem door to door dengan melakukan pembagian sampel CupcakeTauge, penjelasan langkah-langkah pembuatan CupcakeTauge mengacu pada brosur yang dibagikan, dan pengisian kusioner sosialisasi. Kegiatan kedua yaitu produksi CupcakeTauge yang dilaksanakan langsung oleh Mahasiswa selama 4 minggu dengan total 7 kali produksi dan membutuhkan modal sejumlah Rp. 439.220. Kegiatan ketiga yaitu promosi dan pemasaran menggunakan sosial media dan whatsapp broadcast dengan sistem pengiriman produk COD (Cash on Delivery). Kegiatan ini dapat menghasilkan penjualan produk sebanyak 76 kotak Cupcake (isi tiga cup) dengan total keuntungan sebesar Rp. 320.780. Berdasakan data kusioner online yang diisi oleh para konsumen dinyatakan bahwa sebanyak $56,5 \%$ konsumen sangat suka dengan CupcakeTauge dan 39,1\% suka. 60,9\% konsumen ingin membeli kembali produk CupcakeTauge. Maka usaha CupcakeTauge ini dapat dijadikan sebagai peluang usaha yang menjanjikan.
\end{abstract}

Kata Kunci: Cupcake, Tauge, Usaha, Inovasi.

\section{PENDAHULUAN}

Pandemic COVID-19 (Corona Virus Disease 2019) yang melanda seluruh dunia telah memberikan dampak perubahan dari segi pola hidup masyarakat. Menjaga pola makan yang sehat dengan asupan gizi seimbang selama pandemi dapat membantu tubuh untuk mempertahankan daya tahan tubuh dan mencegah penularan Corona Virus Disease.[1] Berkaitan dengan hal tersebut, maka usaha penyediaan makanan sehat memiliki peluang yang cukup besar. Makanan sehat identik dengan buah dan sayur-sayuran. Salah satu jenis sayur yang dikenal sebagai salah satu superfood lokal Indonesia yaitu Tauge.

Tauge adalah kecambah yang berasal dari biji-bijian yang memiliki kandungan senyawa fitokimiawi. Kadar terbanyak kandungan tersebut dalam tauge adalah antioksidan, fitosterol, vitamin $\mathrm{C}$ dan $\mathrm{E}$. Tauge memiliki berbagai manfaat dan keunggulan yaitu dapat mencegah penyakit kanker, serangan jantung, dan dapat meningkatkan sistem kekebalan tubuh.[2] Proses budidaya tauge tidak membutuhkan lahan yang besar dan dapat dipanen dalam waktu yang pendek yaitu tiga hari. Sehingga beberapa masyarakat di wilayah tertentu khususnya wilayah perkotaan tertarik dalam membudidayakan tauge. Salah satunya yaitu masyarakat di wilayah Lingkungan Karang Kateng, Kelurahan Punia, Kecamatan Mataram, NTB. 


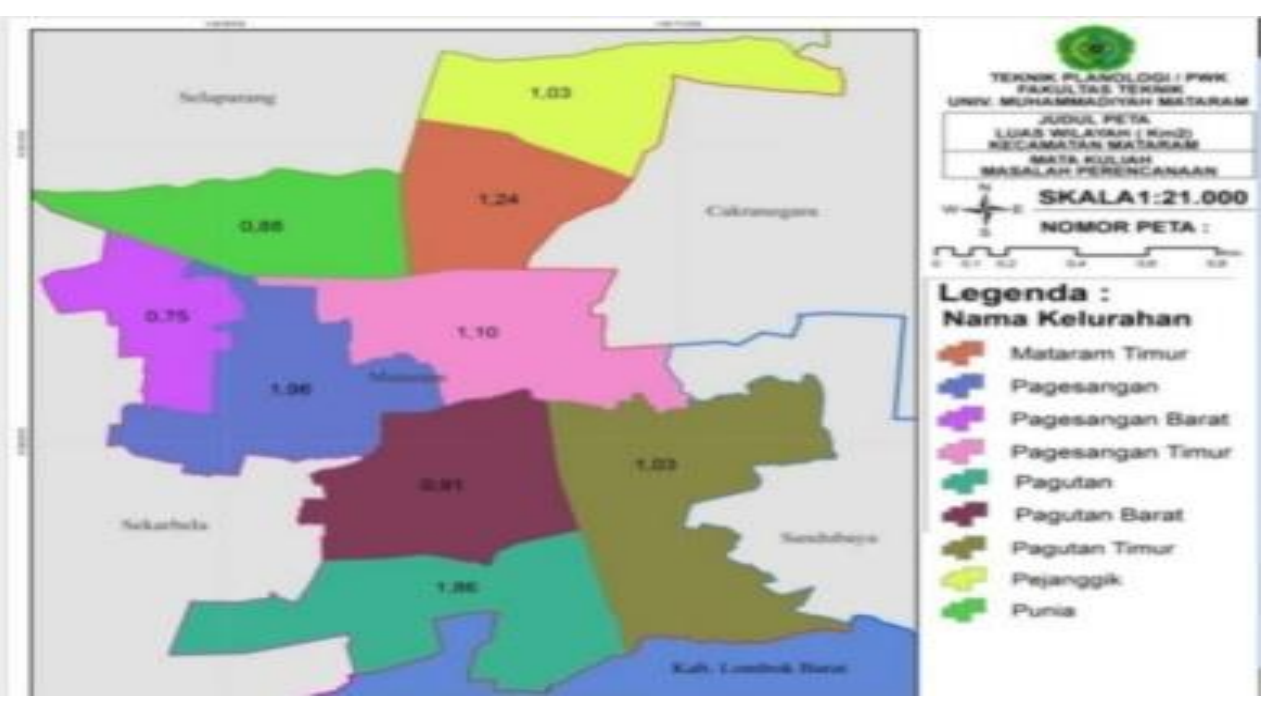

Gambar 1. Lokasi KKN Wilayah Punia (Kode 0.88 warna hijau) Sumber: Perencanaan Wilayah dan Kota Universitas Muhammadiyah Mataram

Secara geografis, Kelurahan Punia merupakan satu dari 9 kelurahan yang berada diKecamatan Mataram dengan luas wilayah, $87.52 \mathrm{Ha} / \mathrm{m} 2$. Kelurahan Punia terletak di Pusat Kota Provinsi Nusa Tenggara Barat yang merupakan daerah dataran dan sebagian wilayahnya berada di pinggiran sungai Ancar. Hampir sebagian besar wilayahnya merupakan daerah perumahan/tempat tinggal dan perkantoran. Jumlah penduduk Kelurahan Punia berdasarkan kelompok pekerjaan di dominasi oleh $36 \%$ masyarakatbelum/tidak bekerja [3]

Hasil observasi menyatakan bahwa, masyarakat wilayah Kelurahan Punia rata-rata sudah memiliki pekerjaan, sebagai pedagang took kelontong dan memiliki pekerjaan turuntemurun sebagai produsen BUSLON (bus-busan dan lontong) atau dalam bahasa Indonesia disebut sebagai tauge dan lontong. Bus-busan merupakan bahasa sasak dari tauge. Masyarakat menjalankan usaha secara individu setiap rumah. Hasil dari lontong dan budidaya tauge hanya di jual secara mentah di pasar atau hanya sebatas dibuat sebagai pendamping makanan. Produk olahan yang dihasilkan bisa dikatakan biasa saja dan tentu dari segi keuntungan dan kualitas olahan tidak cukup menarik.

Berdasarkan potensi dan permasalahan tersebut maka terciptanya usaha berupa inovasi produk olahan dari Tauge yaitu CAPTA (CupcakeTauge) melalui program Kuliah Kerja Nyata (KKN). CAPTA (CupcakeTauge) adalah produk makanan sehat yang dapat dijadikan peluang usaha dalam membantu masyarakatuntukmemenuhi kebutuhan gizi terutama sebagai sumber vitamin, mineral, dan serat. Cupcake merupakan produk berbahan dasar tepung terigu, telur, gula dan susu yang memiliki tekstur padat dan lembut. Keunikan dari produk ini terletak pada penggunaan Tauge sebagai bahan dalam pembuatan dan tampilan cupcake yang membentuk sebuah karakter. Manfaat yangdiharapkan dalam program ini yaitu dapat meningkatkan nilai ekonomis dari tauge dan minat masyarakat Kelurahan Punia khususnya di Lingkungan Karang Kateng dalam mengembangkan pengolahan tauge sebagai potensi wilayah dan bagi masyarakat secara luas dapat dengan mudah menikmati nutrisi dari tauge dengan berbagai olahan.

\section{METODE PELAKSANAAN}

Metode pelaksanaan dalam program Proposal KKN (KuliahKerjaNyata) Era New Normal di Lingkungan Punia Karang Kateng Kelurahan Punia Kecamatan Mataram ini disusun secara sistematis agar sesuai dengan penerapannya. Adapun metode pelaksanaan sebagai berikut:

\section{A. Menentukan Tujuan}

Tujuan utama pengolahan tauge menjadi Cupcake adalah untuk mengembangkan produk olahan sehat dengan kandungan nutrisi yang baik namun dalam bentuk yang menarik dan inovatif, memiliki daya saing baik dari segi produk dan profit serta dapat menjadi salah satuicon produk wilayah Kelurahan Punia. Produk CAPTA (CupcakeTauge). 


\section{B. Observasi Lokasi Dan Pencarian Mitra Tauge}

Observasi lapangan dilakukan untuk mengetahui potensi dan permasalahan yang ada di masyarakat Kelurahan Punia sehingga dalam kegiatan KKN (Kuliah Kerja Nyata) dapat menyelesaikan suatupermasalahan serta mengembangkan potensi wilayah sasaran. Penentuan lokasi pencarian mitra penyediaan tauge yaitu disekitar wilayah posko KKN. Mitra dari usaha ini merupakan salah satu pengerajin tauge yaitu inak icok. Pembelian tauge dilakukan 1 hari sebelum produksi untuk dibersihkan sehingga mempermudah kegiatan produksi.

\section{Izin Pelaksanaan Pihak Kelurahan}

Permohonan izin dan kerjasama dengan pihak Kelurahan Punia melalui kunjungan dan diskusi dengan tujuan untuk melaksanakan Kuliah Kerja Nyata (KKN) dengan tema program Penciptaan 1000 Wirausaha Baru yang memanfaatkan potensi dari Punia yaitu usaha budidaya Tauge. Bekerjasama dengan mitra yaitu pengerajin Tauge sebagai penyediaan bahan produksi dari usaha yang akan dijalankan.

\section{Pembuatan Produk dan Pemasaran}

1. Alat dan bahan

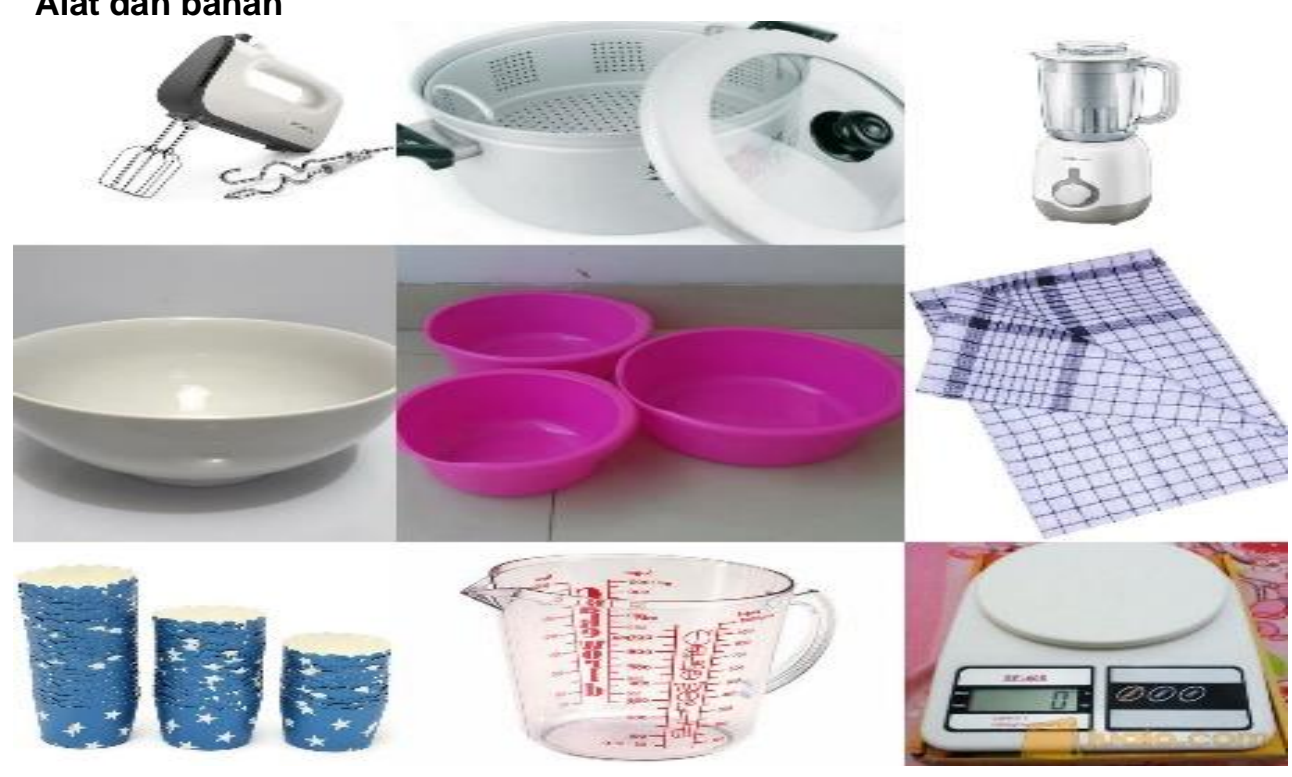

Gambar 2. Alat-Alat Produksi

Alat yang dibutuhkanantara lain mixer, panci kukus, blender, mangkok kecil, baskom, cetakan cupcake, kain (pelapis tutup kukusan), sendok dan spatula, kertas cupcake, saringan, gelasukur, timbangan, pisau. 

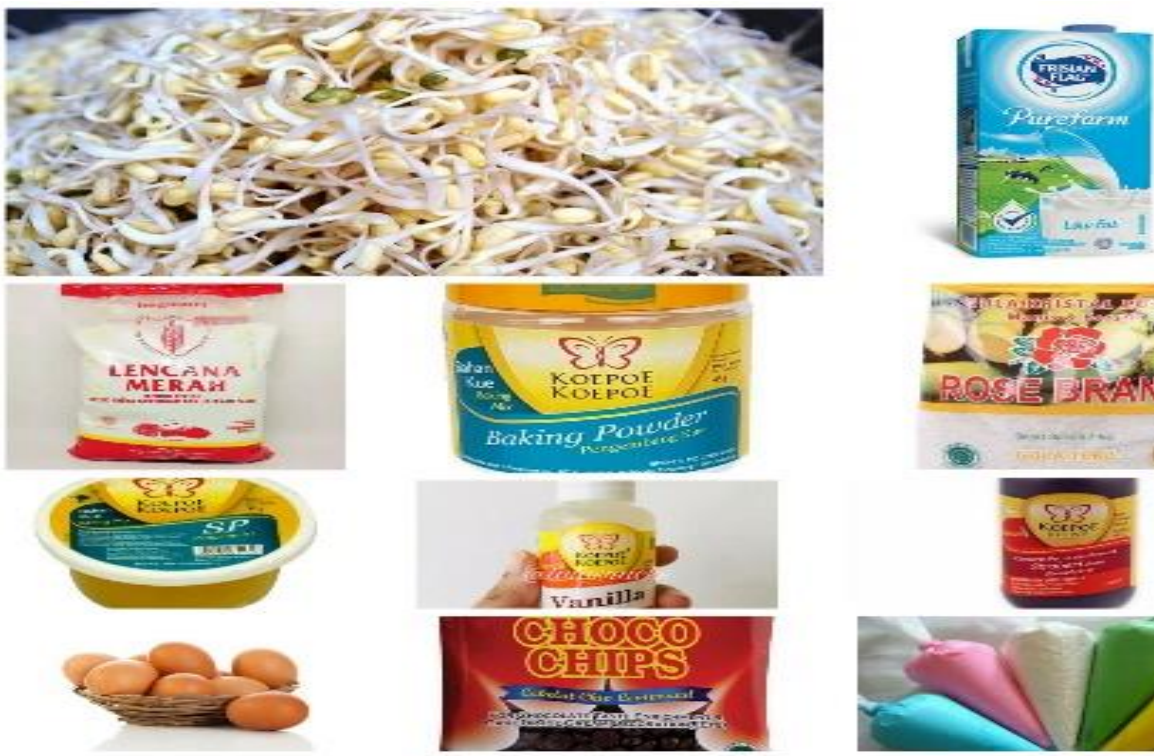

Gambar 3. Bahan-Bahan Produksi

Bahan yang dibutuhkan antara lain $50 \mathrm{gram}$ tauge, $80 \mathrm{ml}$ susu low fat atau susu murni, $140 \mathrm{gram}$ tepung terigu rendah protein (Lencana Merah, bisa gunakan merk lain), 7gram baking powder, 105gram gula pasir, $1 \mathrm{sdt} \mathrm{sp}, 11 / 2 \mathrm{sdt}$ vanili, 2 sdt pewarna dan perisa makanan (atau boleh sesuai selera), 2 butir telur, $25 \mathrm{gram}$ choco chips, selai strawberry, vanilla, dan coklat (sesuai selera).

\section{Cara Pembuatan}

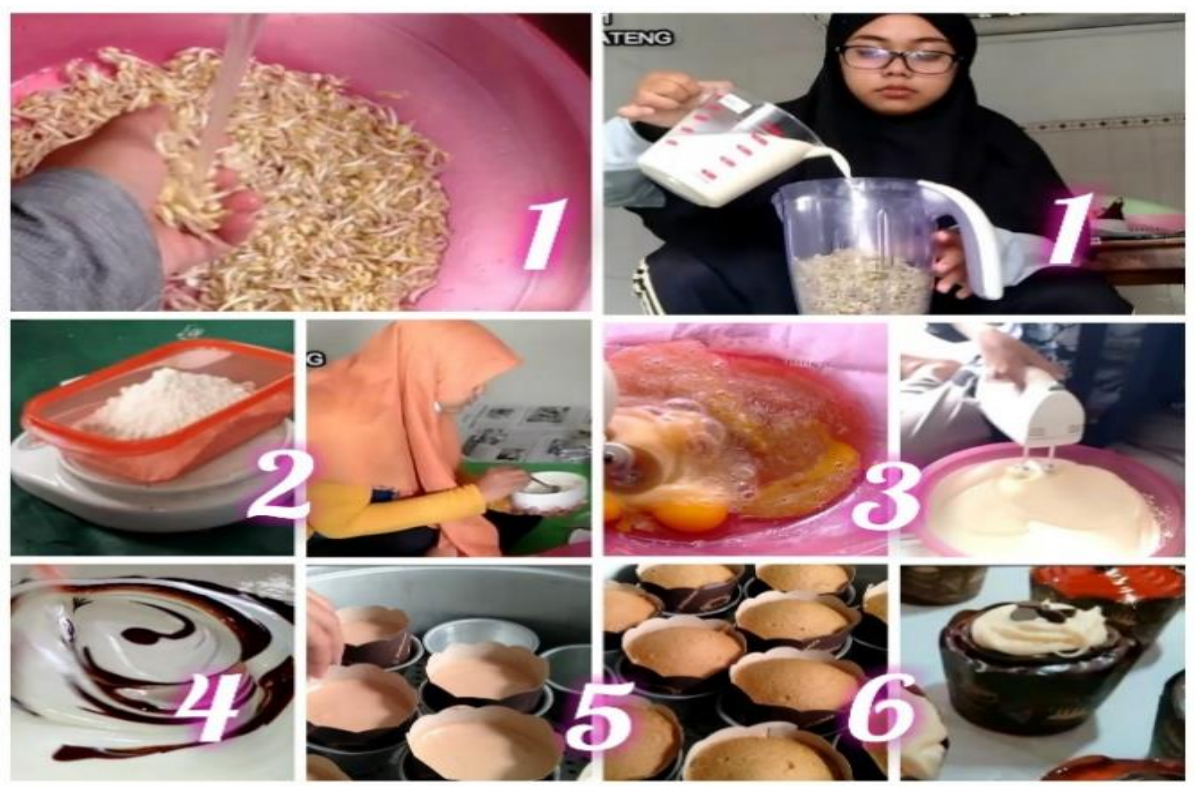

Gambar 4. Tahap-Tahap Pembuatan Produk CupcakeTauge

1) Persiapkan bahan campuran basah. Bersihkan 50 gram kulit tauge dari kulit ari dan pangkal akar. Rebus tauge selama 5 menit dengan tujuan untuk membunuh mikroba patogen yang ada pada tauge. Campurkan 50gram tauge dan $80 \mathrm{ml}$ susu menggunakan blender hingga halus Saring campuran tauge dan susu hingga diperoleh $80 \mathrm{ml}$ sari susu tauge kemudian ditambahkan vanili. 
2) Persiapkan bahan campuran kering. Siapkan tepung rendah protein dan baking powder. Campurkan tepung rendah protein dan baking powder hingga merata.

3) Siapkan telur, gula, dan sp. Bahan di mixer hingga mengembang, pucat, dan berjejak.

4) Masukan bahan kering dan basah secara bergantian, lalu aduk kembali menggunakan mixer. Pastikan adonan tercampur rata dan tidak ada gumpalan tepung.

5) Masukan pewarna dan perisa makanan.

6) Masukan adonan ke dalam kertas cupcake dan berikan choco chips sesuai selera

7) Letakan cetakan cupcakeyang berisi adonan ke dalam kukusan yang telah di panaskan sebelumnya, kemudian kukus selama 10 menit dengan api sedang. Jangan lupa melapisi tutup kukusan dengan kain

8) Setelah matang, dinginkan sebentar, lalu beri toping sesuai dengan selera

3. Promosi dan PemasaranProduk

Promosi dan pemasaran dilakukan dengan metode Open Pre Order melalui media sosial berupa Facebook, Whatsapp dan Instagram. Selain melalui media sosial, promosi juga dilakukan secara langsung dengan orang orang terdekat. Sistem pengantaran dilakukan dengan sistem COD (CashOn Delivery).

\section{E. Sosialisasi Produk Olahan Tauge}

Sosialisasi inovasi produk ke masyarakat wilayah Kelurahan Punia dengan sistem door to door (rumah ke rumah) dengan cara pembagian brosur yang berisi tentang CupcakeTauge baik dari segi latar belakang poduk dan cara pembuatan. Selain itu, dilakukan kegiatan pembagian sampel produk untuk dinilai masyarakat setempat melalui kusioner yang sudah dibagikan.

\section{HASIL DAN PEMBAHASAN}

\section{A. Produksi Cupcake Tauge}

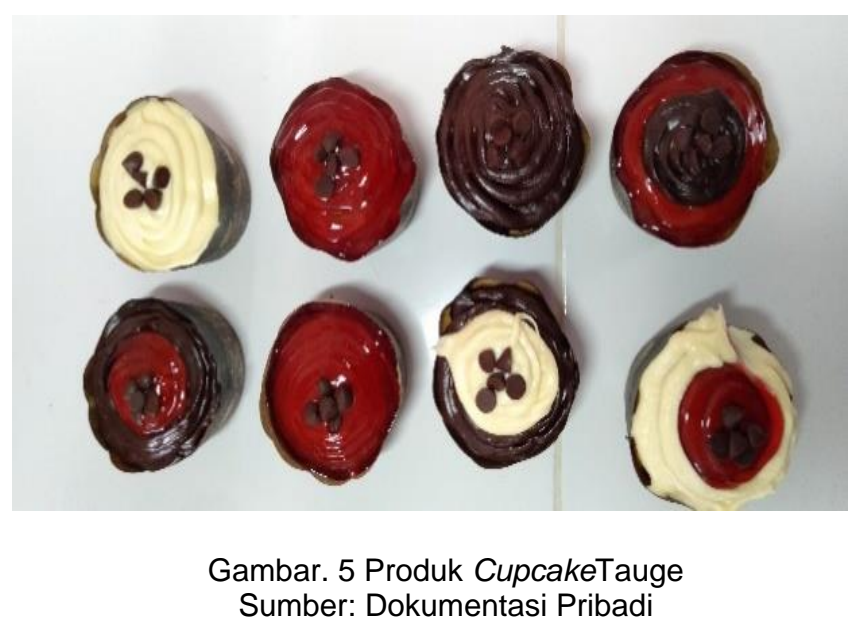

\section{B. Produksi CupcakeTauge}

Kegiatan produksi dilaksanakan sebanyak 7 kali selama 4 minggu. Selama produksi, terjadi beberapa perubahan yaitu dari penambahan choco chips di produksi pertama dan penambahan toping selai (strawberry, keju, vanilla, blueberry, dan coklat). Perubahan ini terjadi karena adanya kritik dan saran dari para konsumen. Modal awal dari pembuatan CupcakeTauge ini sejumlah Rp 482.000 terdiri dari pembelian bahan baku dan penunjang. Kegiatan produksi ini menghasilkan sebanyak 20 kali adonan. Dalam 1 kali adonan ini menghasilkan 9 CupcakeTauge (3 kotak) dengan modal secara keselurahan dari adonan dan bahan habis pakai sejumlah Rp. 21.961. Sehingga selama 7 kali produksi (20 kali adonan) membutuhkan modal sejumlah Rp. 439.220. 


\section{Promosi Dan Pemasaran Produk}

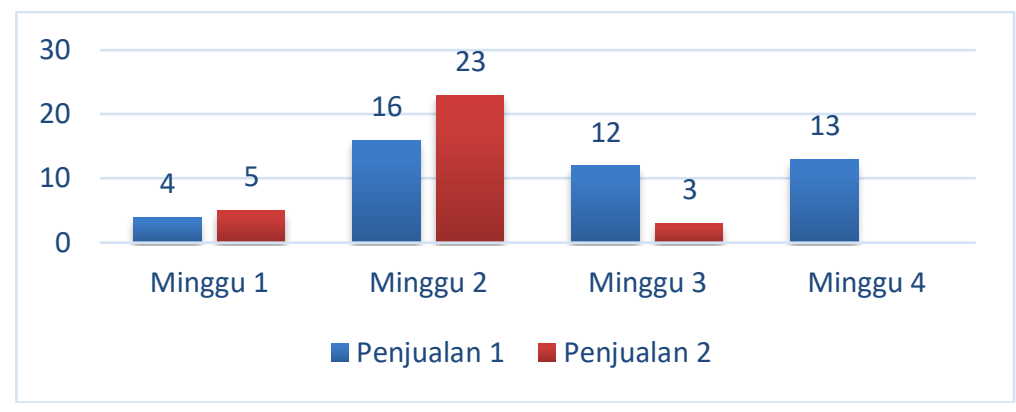

Gambar 6. Grafik Penjualan Produk Cupcake Tauge

Berdasarkan gambar 6, selama 4 minggu kegiatan terhitung sejumlah 7 kali promosi dan pemasaran yang sudah terlaksana dengan total pesanan produk CupcakeTauge yaitu 76 kotak. Penjualan dari minggu ke satu sampai dengan minggu ke dua mengalami peningkatan secara signifikan. Penjualan tertinggi terjadi pada minggu ke dua, pada penjualan ke dua sebanyak 23unit kotak CupcakeTauge. Pada minggu ke tiga dan ke empat terjadi penurunan penjualan. Hal ini terjadi dikarenakan pada saat minggu ke dua para tim produksi mengalami penurunan kesehatan sehingga membatasi penjualan produk. Jumlah penjualan produk sudah memenuhi target awal penjualan yaitu sebanyak minimal 75 kotak terjual. Berdasarkan perhitungan tersebut didapatkan bahwa total laba atau keuntungan setengah bersih diluar biaya gas dan listrik yaitu Rp. 320.780.Setiap pemesan akan diarahkan untuk mengisi kuisioner online yang diisi sebanyak 23 responden.

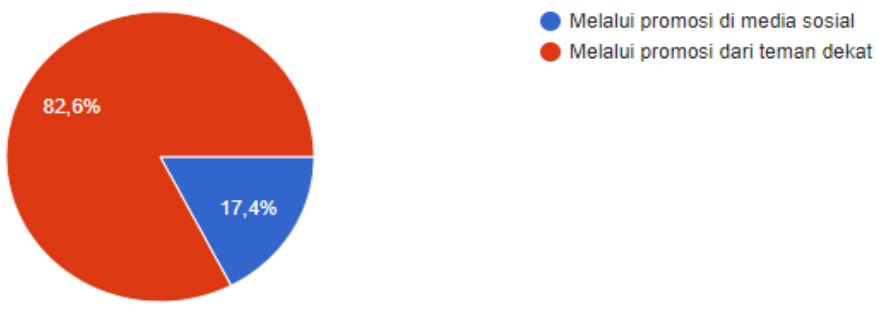

Gambar 7. Media Promosi Produk Cupcake Tauge

Berdasarkan gambar 7, sebanyak $82,6 \%$ pelanggan mengetahui produk CupcakeTauge melalui teman dekat dengan sistem broadcast whatsapp. Promosi melalui media ini sangat efektif karena dapat menjadi salah satu pilihan awal dalam mempromosikan produk CupcakeTauge melalui jaringan pertemanan dekat. Sebanyak $17,4 \%$ pelanggan mengetahui produk CupcakeTauge melalui media sosial Instagram dan Facebook.

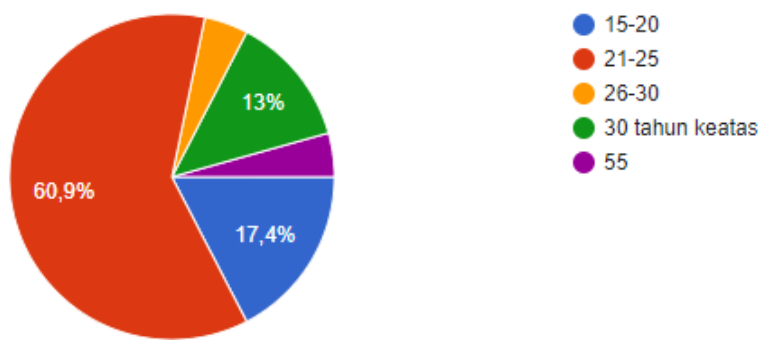

Gambar 8. Usia Konsumen Produk CupcakeTauge 
Berdasarkan gambar 8, target marketing dari produk CupcakeTauge disasarkan untuk semua kalangan dengan berbagai lintas usia. Namun, rata-rata usia konsumen didominasi oleh usia 21-25.

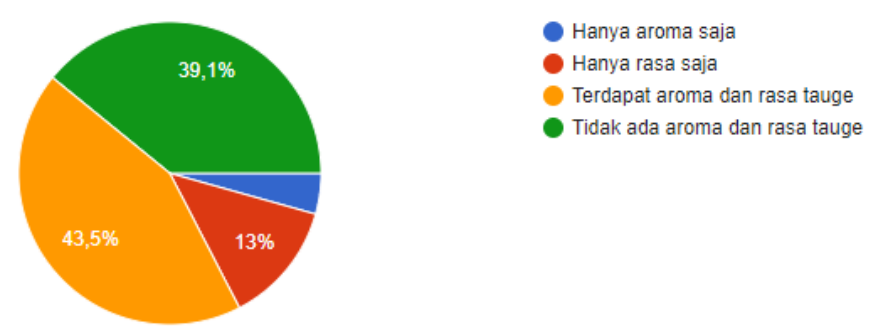

Gambar 9. Uji Sensori Produk CupcakeTauge

Hasil data uji sensori dan daya terima dari konsumen pada gambar 9 , menunjukkan bahwa 43,5\% konsumen dapat merasakan aroma dan rasa tauge dan sebanyak $39,1 \%$ konsumen tidak merasakan adanya aroma dan rasa tauge. Dua hasil data tersebut memiliki presentase yang hampir sama, hal ini disebabkan karena beberapa faktor yaitu poses perebusan yang tidak terlalu matang mengakibatkan adanya rasa aroma tauge yang masih tertinggal, selain itu tingkat aroma tauge pada cupcake dipengaruhi oleh jarak waktu saat pengukusan dan saat cupcake dikonsumsi. Namun, ada atau tidaknya rasa dan aroma tauge tidak mempengaruhi tingkat kesukaan konsumen.

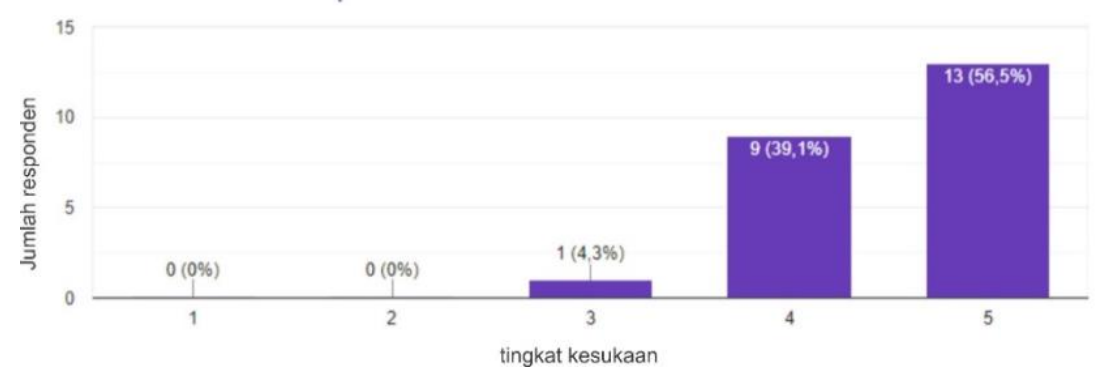

Gambar 10. Tingkat Kesukaan Pemesan Produk CupcakeTauge

Data gambar 10, menunjukkn sebanyak 56,5\% konsumen sangat suka dengan CupcakeTauge dan 39,1\% suka. Konsumen produk CupcakeTauge memiliki minat yang cukup tinggi, yaitu sebanyak 60,9\% konsumen ingin membeli kembali produk CupcakeTauge.

\section{Sosialisasi Produk CupcakeTauge}

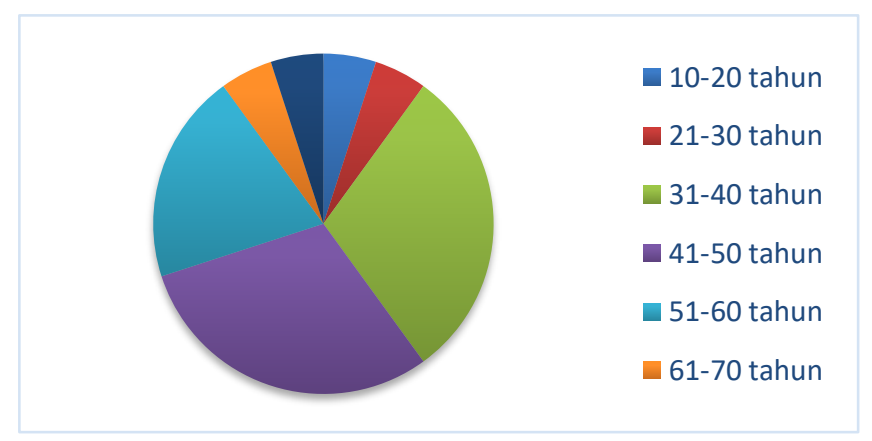

Gambar 11. Diagram Usia Peserta Sosialisasi

Berdasarkan gambar 11, kegiatan sosialisasi produk CupcakeTauge dilaksanakan dengan sistem door to door yaitu peserta sosialisasi di dominasi oleh usia 31-50 tahun yaitu 
sebesar $60 \%$. Rangkaian kegiataan sosialisasi terdiri dari: penjelasan dan pembagiaan brosur yang berisikan informasi latar belakang terciptanya produk inovasi CupcakeTauge, alat dan bahan serta cara pembuatan. Pembagian sampel produk CupcakeTauge ke para peserta sosialisasi dan pembagian kusioner.

Luaran dari kegiatan sosialisasi dalam bentuk kusioner yang diisi oleh peserta sosialisasi. Sebanyak $74 \%$ peserta tidak merasakan adanya aroma dan rasa tauge pada cupcake. Hal ini bisa disebabkan oleh beberapa faktor antara lain karena tauge melalui tahap perebusan dan adanya penambahan vanili sebagai penambah aroma. Namun faktor tersebut menyebabkan para peserta menyukai produk cupcake, hal ini dapat dilihat sebanyak $48 \%$ peserta sangat menyukai CupcakeTauge dan 47\% sisanya suka. Harga jual CupcakeTauge dianggap cukup terjangkau dan sesuai dengan kualitas produk, hal ini terlihat dari data bahwa sebanyak 74\% peserta berminat membeli produk tersebut dengan harga 10.000 .

\section{KESIMPULAN}

Berdasarkanpembahasan di atasmakadapatdisimpulkanbahwa usaha inovasi produk olahan tauge berupa CAPTA (CupcakeTauge) dapat dijadikan peluang usahauntuk mengoptimalkan potensi dan sebagai solusi dalam mengurangi tingkat pengangguran di masyarakat. Modal produksi yang dibutuhkan sebesar Rp.21.961 untuk menghasilkan 9 CupcakeTauge. Hasil produksi dan penjualan CAPTA (CupcakeTauge) memenuhi target penjualan yaitu 76 kotak CupcakeTauge terjual dengan harga Rp.10.000. Total keuntungan bersih yang didapatkan sebesar Rp. 320.780. Hasil data kusioner menunjukkan bahwa 56,5\% konsumen sangat suka denganproduk CAPTA (CupcakeTauge) dan $39,1 \%$ suka. Konsumen mengharapkan adanya penambahan variasi rasa dan meningkatkan aroma vanili pada CupcakeTauge.

\section{SARAN}

Inovasi produk CAPTA (CupcakeTauge) dapat lebih dikembangkan menjadi suatu usaha makanan di Punia dan dapat dilanjutkan oleh Aparat Desa yaitu PKK (Pemberdayaan Kesejaheraan Keluarga) serta masyarakat sekitar wilayah Punia.

\section{UCAPAN TERIMA KASIH}

Segala puji senantiasa penulis haturkan kehadirat AllahSWT yang telah melimpahkan rahmat dan Hidayah-Nya sehingga penulis dapat menyelesaikan program KKN (Kuliah Kerja Nyata) Era New Normal di Lingkungan Karang Kateng, Punia.

Dalam pelaksanaan program ini tidak akan lepas dari adanya bantuan, bimbingan dan nasihat dari semua pihak yaitu: 1. Jajaran pimpinan Universitas Mataram (LPPM) yang telah memberikan kesempatan kepada para mahasiswa dalam program KKN (Kuliah Kerja Nyata) Era New Normal; 2. Para orang tua yang selalu memberi dukungan materi dan moril dalam menjalani pendidikan di Universitas Mataram;3. Bapak Sultan, ST., MTselaku Dosen Pembimbing Lapangan yang telah membimbing dan mengarahkan dalam program pengabdian ini; 4. Bapak Kepala KelurahanPunia yang telah memberikan kami perizinan pelaksanaan programini; 5 . Semua Mitra kami dalam hal ini Masyarakat Lingkungan Karang Kateng selama 45 hari ( 1,5 bulan) telah bekerjasama dengan baik dalam Program.

\section{DAFTAR PUSTAKA}

[1] Tampatty, G. C., N. S. H. Malonda, M. D. Amisi. 2020. Gambaran Pola Makan Pada Tenaga Pendidik Dan Kependidikan Fakultas Kesehatan Masyarakat Universitas Sam Ratulangi Selama Masa Pandemi COVID-19. KESMAS, 9(6): 46-52.

[2] Mahandika, T. G. R., Kusnila., A. Aisyah, Warjito., H. H. Pranata. 2019. Brownies Tauge Coklat. WASANA NYATA: Jurnal Pengabdian kepada Masyarakat. 3(1): 135-136.

[3] Pemerintah Kota Mataram Kelurahan Punia. 2018. Profil Kelurahan Punia Tahun 2018. Pemerintah Kota Mataram Kelurahan Punia. 